\title{
GIS-based hydrogeological databases and groundwater modelling
}

\author{
Radu Constantin Gogu • Guy Carabin • Vincent Hallet \\ Valerie Peters · Alain Dassargues
}

\begin{abstract}
Reliability and validity of groundwater analysis strongly depend on the availability of large volumes of high-quality data. Putting all data into a coherent and logical structure supported by a computing environment helps ensure validity and availability and provides a powerful tool for hydrogeological studies. A hydrogeological geographic information system (GIS) database that offers facilities for groundwater-vulnerability analysis and hydrogeological modelling has been designed in Belgium for the Walloon region. Data from five river basins, chosen for their contrasting hydrogeological characteristics, have been included in the database, and a set of applications that have been developed now allow further advances. Interest is growing in the potential for integrating GIS technology and groundwater simulation models. A "loose-coupling" tool was created between the spatial-database scheme and the groundwater numerical model interface GMS (Groundwater Modelling System). Following time and spatial queries, the hydrogeological data stored in the database can be easily used within different groundwater numerical models.
\end{abstract}

Résumé La validité et la reproductibilité de l'analyse d'un aquifère dépend étroitement de la disponibilité de grandes quantités de données de très bonne qualité. Le fait de mettre toutes les données dans une structure cohérente et logique soutenue par les logiciels nécessaires aide à assurer la validité et la disponibilité et fournit un outil puissant pour les études hydrogéologiques. Une base de données pour un système d'information géographique (SIG) hydrogéologique qui offre toutes les facilités

Received: 4 April 2000 / Accepted: 26 October 2001

Published online: 8 December 2001

(C) Springer-Verlag 2001

R.C. Gogu

Department of Cartography,

Swiss Federal Institute of Technology (ETH),

ETH Hoenggerberg, 8093 Zurich, Switzerland

G. Carabin · V. Hallet · V. Peters · A. Dassargues (

University of Liege, Laboratory of Engineering Geology,

Hydrogeology and Geophysical Prospecting, B19 Sart Tilman,

4000 Liege, Belgium

e-mail: alain.dassargues@ulg.ac.be

Fax: +32-43-662817 pour l'analyse de la vulnérabilité des eaux souterraines et la modélisation hydrogéologique a été établi en Belgique pour la région Wallonne. Les données de cinq bassins de rivières, choisis pour leurs caractéristiques hydrogéologiques différentes, ont été introduites dans la base de données, et un ensemble d'applications qui ont été développées permet dès maintenant de prochaines avancées. L'intérêt grandit pour le potentiel d'intégration de la technologie des SIG et les modèles de simulation des nappes. Un outil de couplage a été créé entre le schéma de base de données spatiales et l'interface GMS (GroundWater Modelling System, système de modélisation de nappe) du modèle numérique de nappe. Suivant les requêtes en fonction du temps et de l'espace, les données hydrogéologiques stockées dans la base de données peuvent être aisément utilisées dans différents modèles numériques de nappes.

Resumen La fiabilidad y validez de los análisis de aguas subterráneas dependen enormemente de la disponibilidad de muchos datos de alta calidad. Integrarlos en una estructura consistente y lógica mediante un entorno informático sirve para asegurar su validez y disponibilidad, y rrepresenta una herramienta muy potente para ulteriores estudios hidrogeológicos. Se ha diseñado en la región de Valonia (Bélgica) una base de datos hidrogeológica basada en un sistema de información geográfica (GIS), con el que se dispone de útiles para elaborar análisis de vulnerabilidad y modelos hidregeológicos. Se ha utilizado datos de cinco cuencas fluviales, elegidas por sus características hidrogeológicas contrastadas, así como un conjunto de aplicaciones desarrolladas con vistas al futuro. El interés por el potencial que ofrece la integración de la tecnología GIS y los modelos de simulación de aguas subterráneas está en auge. Se ha desarrollado un "emulador" que integra el esquema espacial de la base de datos y la interfaz GMS (GroundWater Modelling System) de modelación numérica de aguas subterráneas. A partir de búsquedas temporales y espaciales, los datos hidrogeológicos almacenados en la base de datos pueden ser utilizados fácilmente en modelos numéricos diferentes de aguas subterráneas.

Keywords Groundwater management .

Database management - Geographic Information Systems . Numerical modelling $\cdot$ Belgium 


\section{Introduction}

In recent years, the use of the Geographic Information System (GIS) has grown rapidly in groundwater management and research. GIS is now widely used to create digital geographic databases, to manipulate and prepare data as input for various model parameters, and to display model output. These functions allow primarily overlay or index operations, but new GIS functions that are available or under development could further support the requirements of process-based approaches.

A GIS-managed hydrogeological database has been developed in order to support data used in vulnerabilityassessment techniques and numerical modelling for groundwater flow and contaminant-transport studies. The database contains the hydrogeological specificity of the environment of the Walloon region, Belgium. In addition, the coupling between the database and processbased numerical models was implemented. Subsequent projects have dealt with the preparation of groundwaterquality maps and hydrogeological maps.

Work with hydrogeological data and the study of several commercial hydrogeological database schemes, such as ERMA (Environmental Resource Management Applications; Intergraph 1995), have led to the intent to design the scheme of a new hydrogeological spatial database. A need exists for an advanced structure to be used for different environmental studies and consulting activities as well as research and modelling. The design has to address: (1) data management, processing, and analysis, as well as hydrogeological-map production; (2) numerical modelling, as well as overlay and index techniques used in aquifer vulnerability assessment; and (3) support for water authorities' decision-making processes.

\section{GIS and Hydrogeology}

\section{Representation of Data and Databases}

Data and information required by hydrogeological studies are complex. Information concerning geology, hydrology, geomorphology, soil, climate, land use, topography, and man-made (anthropogenic) features needs to be analysed and combined. Data are collected from existing databases and maps as well as through new field measurements.

Point automatic-collecting systems for some of the physical and chemical parameters are being increasingly used. So too are remote-sensing techniques to assess parameters related to soil, the unsaturated zone, geomorphology, and climate. Some of the techniques for measurement of hydrogeological parameters (sampling, monitoring of hydraulic heads and flow rates, geophysical techniques) show a steady improvement. All these data need to be managed, and this can be achieved using databases, particularly GIS databases.

Storing data implies data analysis, conceptual design of data models, and data representation. In hydrogeology, because of a limited number of sample locations, point- attribute data also need to be processed by applying adequate kinds of interpolation or modelling algorithms. The derived data also need to be managed.

\section{Basic Concepts of GIS}

A GIS is defined as a system for input, storage, manipulation, and output of geographically referenced data (Goodchild 1996). GIS provides a means of representing the real world through integrated layers of constituent spatial information (Corwin 1996). Geographic information can be represented in GIS as objects or fields. The object approach represents the real world through simple objects such as points, lines, and areas. The objects, representing entities, are characterised by geometry, topology, and non-spatial attribute values (Heuvelink 1998).

In hydrogeology, some examples of spatial objects are wells, piezometers, boreholes, galleries, and zones of protection. Attribute values of objects could be the number of a well, the ownership, and the diameter of a gallery or drain. The field approach represents the real world as fields of attribute data without defining objects; some examples are strata elevation, hydraulic head, and vulnerability zones. This approach provides attribute values in any location. In GIS, this distinction between objects and fields is often associated with vector data models and raster data models. The vector model represents spatial phenomena through differences in the distribution of properties of points, lines, and areas. In this system, each layer is an adapted combination of one or more classes of geometrical features. A raster model consists of a rectangular array of cells with values being assigned to each cell. In the raster model, each cell is usually restricted to a single value. Thus, representing the spatial distribution of a number of parameters or variables requires multiple layers.

In their work, environmental specialists need to have available clear representations of the spatial variation of the data. In GIS, two ways exist to solve this problem: (1) field variables (a variable can be given a single, welldefined value at every location), and (2) kernel functions (spatially continuous functions). For digital representation of the spatial variation characterised by fields, six methods are distinguished: the raster model, grid model (rectangular array of sample points), point model (areally irregularly distributed sample points), contour model (isolines), polygon model (polygons holding average attribute values), and triangular irregular network (TIN).

Storing and manipulating data through spatial relationships can be achieved with the GIS packages using the "georelational" model or the "geodatabase" model. The first consists of linking a relational database to geometrical features. The modelled entities are organised into categories sharing common characteristics (points representing wells, piezometers, or gallery wells). A table represents each category. The different attributes occur as columns of the table, and the rows assure the data registration. Relationships "one to one" or "one to 
Fig. 1 Example of representing hydrogeological features using the georelational model

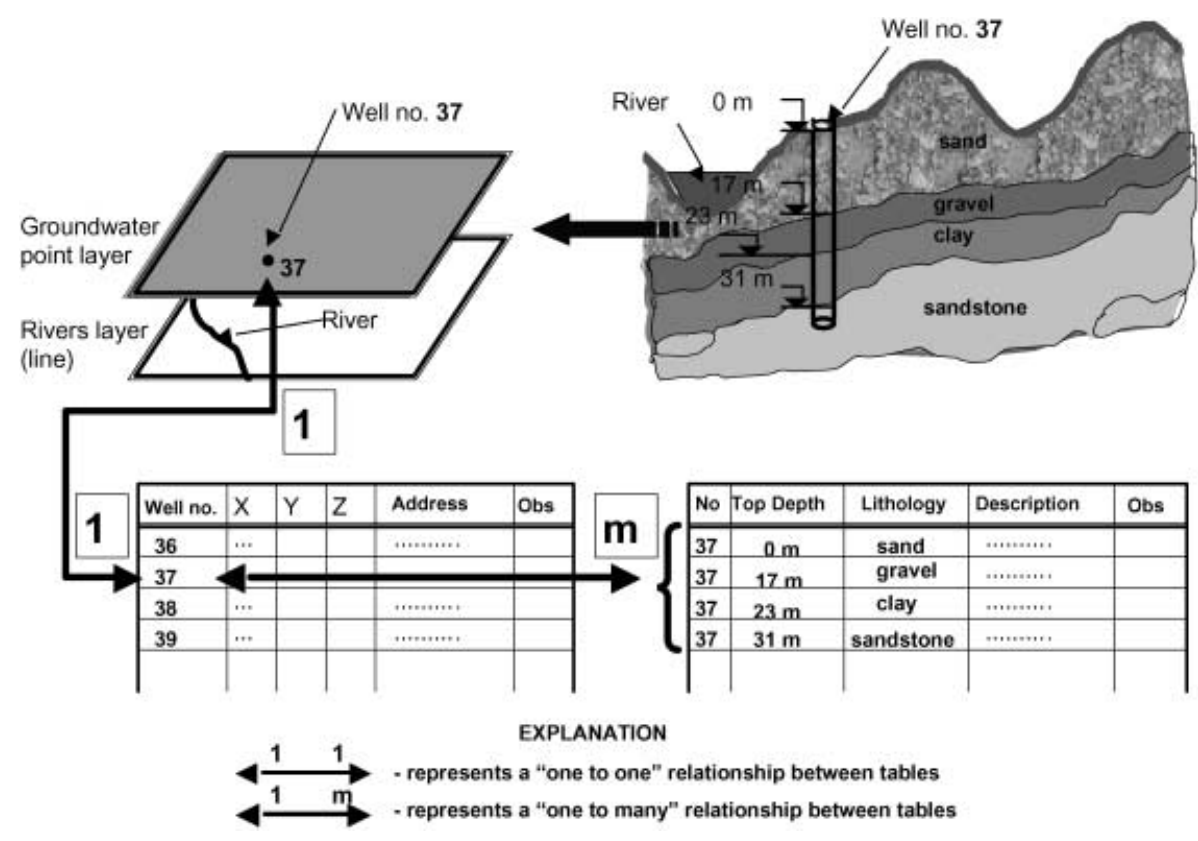

many" can be established between tables (Levene and Loizou 1999).

A small example can make the georelational model more comprehensible. In GIS, the real world is described using digital-map data, which define positions in space, and attribute data, which usually consist of alphanumeric lists of characteristics and, frequently, temporal information describing when the other data are valid in time. The various objects, such as rivers or wells, are represented on different layers using an appropriate geometry; the rivers are represented as lines, the wells as points. Attribute data may be converted to graphic symbols presented together with other data on a map. Simply moving a pointer to a symbol on a screen display and entering a command can retrieve the attribute data. Geometric data and attribute data are usually separated in the software hierarchy. Identical identifiers for the two kinds of data (geometric and attribute) facilitate matching for retrieval and processing. Figure 1 shows a geological cross section. The point element of the digital-map layer possesses the identifier 37 and represents the well number 37. The same identifier 37 can be found in the first table of Fig. 1 containing the well locations. This represents a "one to one" relationship; one point on the map related to one row. The well number 37 penetrates the sand, gravel, clay, and sandstone strata. This is described in the second table of Fig. 1, such that the user knows that sand is found between 0 and $17 \mathrm{~m}$, gravel between 17 and $23 \mathrm{~m}$, clay between 23 and 31, and sandstone starting from $31 \mathrm{~m}$ depth. All rows describing the lithology of well number 37 have the same identifier. This represents a "one to many" relationship. Data presenting a temporal variation such as hydraulic heads or pumping rates are represented in a similar way.

If the georelational model uses points, lines, polygons, and related attribute tables to define various properties in the geodatabase model, entities are represented as objects with properties, behaviour, and relationships. For example, a well object can be found within a library of objects with the entire attribute scheme attached. The user can simply take it, place it on the map, and enter the data in the attached tables. The georelational and geodatabase models are actually very similar. However, the geodatabase model represents a recent improvement in the implementation of the georelational model.

\section{Assembling Groundwater Models and GIS}

Geographic data processing can be seen as a subfield of data processing in general. A clear distinction exists between geographic data processing and process-based modelling. In order to create a digital version of the real geographic form or pattern, geographic features and attributes have to be modelled. For understanding and prediction behaviour, process-based modelling uses the equations that describe the physical or biochemical processes that are to be simulated. Between these two forms of modelling, useful relationships can be established.

Most of GIS can easily accomplish overlay and index operations, but cannot perform the process-based groundwater modelling functions related to groundwater flow and transport processes. However, coupling a GIS to "process-based" models can provide an efficient tool for processing, storing, manipulating, and displaying hydrogeological data. Even though process-based models do not require the use of GIS, a well-designed GIS can significantly reduce the time needed for data preparation and presentation.

The process-based models used in hydrogeology include the simulation of steady- or transient-state groundwater flow, advection, hydrodynamic dispersion, adsorption, desorption, retardation, and multi-component chemical reaction. Very often, exchanges with the unsaturated 
Fig. 2 General framework for integrating the hydrogeological database, as support for study of the impact of climatic changes in the hydrological cycle at the small basin scale

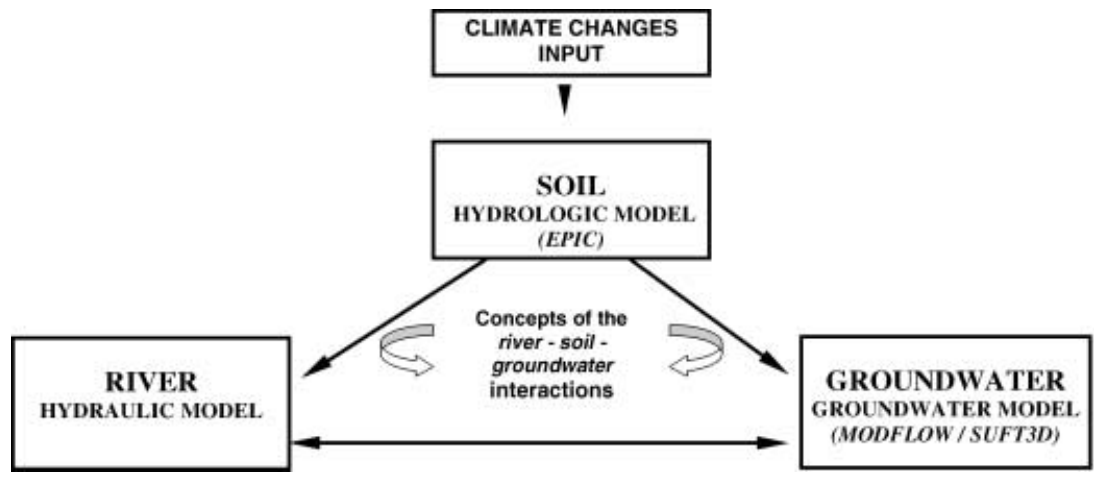

zone and with rivers are also addressed. In these models, equations based on physical processes are solved.

Modelling groundwater flow and contaminant transport in aquifers represents a spatial and temporal problem that requires the integration of deterministic processbased models with GIS. In order to model the physical and chemical processes in the aquifer, each model parameter or variable is represented on a three- or fourdimensional (x, y, z, and time) information layer. Due to the heterogeneity of aquifers, representing the spatial distribution of the parameters and variables that are involved in the constitutive laws describing the simulated processes creates a huge data volume. Managing these data can be done most effectively through GIS.

Data used in groundwater modelling consist of four categories: (1) the aquifer-system stress factors, (2) the aquifer-system and strata geometry, (3) the hydrogeological parameters of the simulated process; and (4) the main measured variables. Stress factors for groundwater flow include: effective recharge, pumping volumes, water-surface flow exchanges, etc. In contaminant-transport modelling, the input and output contaminant mass flows are stress factors. These stress factors are imposed on the model through the "boundary" conditions or "source/ sink" terms. An appropriate aquifer-system geometry can be determined using geological information (maps and cross sections), topographic maps, and contour maps of the upper and lower limits for the aquifer strata and aquitards. Initial estimates of the distributed values and spatial distributions of the hydrogeological parameters (hydraulic conductivity, storage coefficient, dispersivity, etc.) need to be made using raw data and interpretations. Of course, the interpretation is based on knowledge of the aquifer geology and hydrogeology. Maps and cross sections representing the spatial variations of hydrogeological parameter values are used. For a flow problem, the main measured variable is the hydraulic head, and for a contaminant-transport problem, it is the contaminant concentration. These consist of point values measured at different time periods in the entire aquifer. They are required for model calibration and validation.

Links can be organised between models and GIS using three techniques: loose coupling, tight coupling, and embedded coupling. Loose coupling is when the GIS and the model represent distinct software packages and the data transfer is made through input/output model predefined files. The GIS software is used to pre-process and post-process the spatial data. An advantage of this solution is that the coupled software packages are independent systems, facilitating potential future changes in an independent manner. In tight coupling, an export of data to the model from GIS is performed, but the GIS tools can interactively access input model subroutines. In this case, the data exchange is fully automatic. An example of this coupling is the groundwater modeller link (Steyaert and Goodchild 1994) between the ERMA spatial database scheme [supported by modular GIS environment; Intergraph (1995)] and MODFLOW, MODPATH, and MT3D finite-difference software packages. When a model is created using the GIS programming language or when a simple GIS is assimilated by a complex modelling system, embedded coupling is used. Tight coupling as well as embedded coupling involves a significant investment in programming and data management that is not always justified. Also, this could be constraining when changes are required.

\section{Applications of GIS Data Processing for Groundwater Numerical Modelling}

For groundwater studies, four main distinct applications of GIS are recognised: (1) the management of hydrogeological data and general hydrogeological analysis, (2) hydrogeological map elaboration, (3) vulnerability assessment (based on overlay and index methods), and (4) hydrogeological database support for process-based numerical modelling. The first three represent the extension in hydrogeology of classical GIS technology. The last one consists mainly of developing interactions between GIS and dynamic models used in groundwater studies.

A good example of developing a hydrogeological database is given by the study of the impact of climate changes on the hydrological cycle at the basin scale. This study was conducted as part of the Belgian research project "Integrated Modelling of the Hydrological Cycle in Relation to Global Climate Change". The modelled system involves the simulation of quantitative interactions between river, soil, and groundwater, as shown in Fig. 2. 
Fig. 3 Schematic representation of applications related to the hydrogeological database and the analysed hydrogeological basins of Geer, Gette, HoyouxNeblon, Orneau, and Ourthe, Belgium

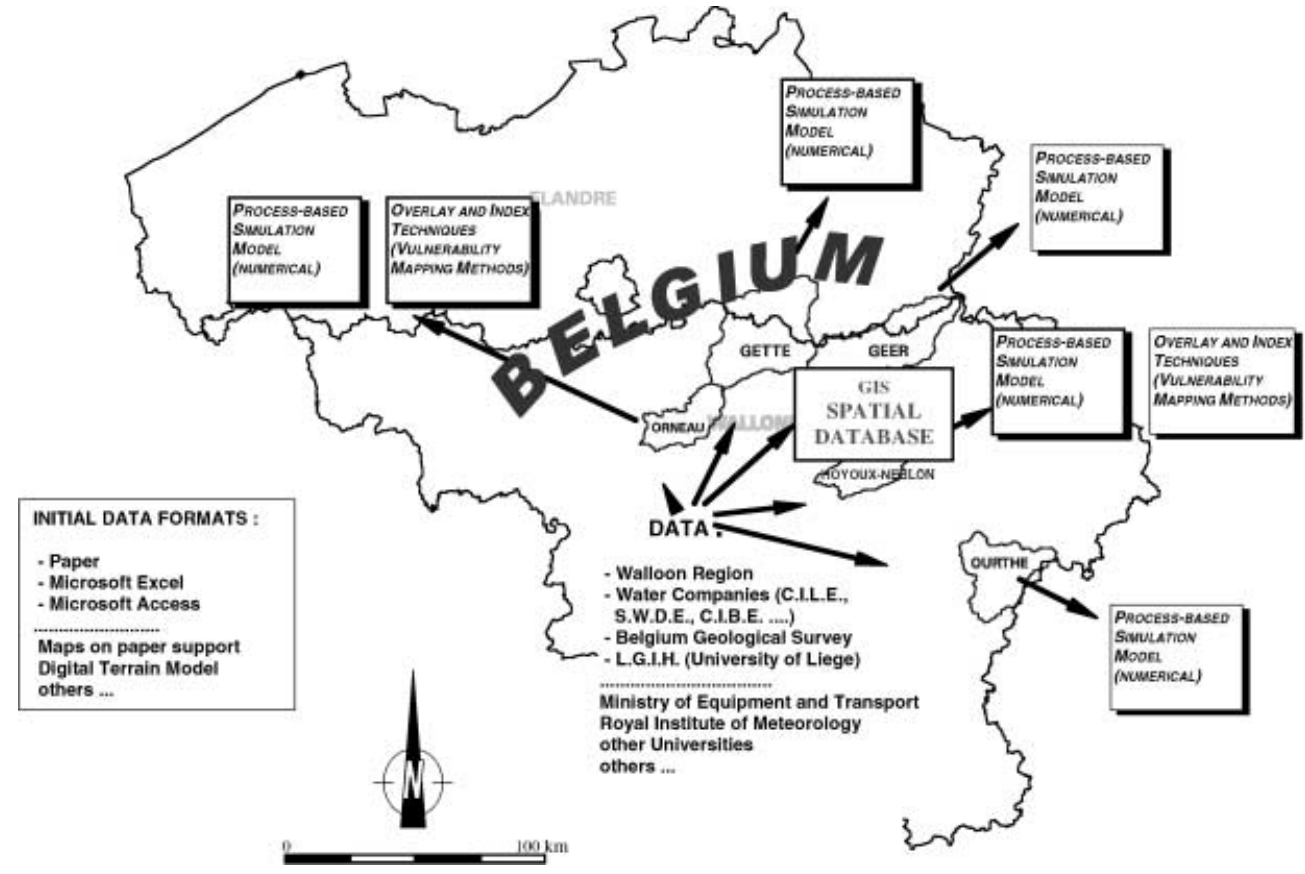

Three process-based models are coupled to simulate the water flow in each of the three media (Fig. 2). The three submodels deal with different compartments of the water cycle. The EPIC-GRID soil model (Sohier et al. 2001) computes a general water budget at the soil surface and in the unsaturated zone, differentiating water between evapotranspiration, overland flow, slow and fast subsurface flows, and percolation. The unsaturated zone includes the root zone in relation to crop growth. The surface-water model deals with water flows in the river network and the groundwater model deals with the groundwater flows and the base-flow at discharge to the rivers. Water fluxes are exchanged between the three sub-models at different locations and over time. To handle these exchanges efficiently, some spatial and temporal mapping procedures had to be developed. Interactions between rivers and aquifers (Carabin and Dassargues 1999; Dassargues et al. 1999) are expressed as computed water-flow rates depending on the difference between the piezometric head in the aquifer and the water level in the river and the dynamic Fourier boundary condition (Carabin and Dassargues 2000). A 1-day time step was chosen for exchange among the three models. However, the soil and river models have internal shorter time steps of $1 \mathrm{~h}$. The groundwater models use finite-element or finite-difference software. For application, five hydrogeological basins were chosen for their contrasting hydrogeological characteristics: Gette (sand and chalk), Geer (chalk), Hoyoux-Neblon (limestone and sandstone), Orneau (sand and limestone), and Ourthe (fissured-shale bedrock). Locations are shown in Fig. 3. The Gette, Geer, and Orneau basins are located in areas where intensive agricultural activities take place in addition to urban zones of small cities (less than 25,000 inhabitants). The Hoyoux-Neblon and Ourthe basins are extensive livestock farming areas with only small villages and with a high portion of forested areas in the Ourthe basin.

Specific aspects of the integration of these three models and on the calibration and results of the integrated model applied to these basins are described in an internal report (Belgian Office for Scientific, Technical and Cultural Affairs 2001) and will probably be published very soon.

\section{An Advanced Approach for Managing Hydrogeological Data: The HYGES Database Scheme}

Recognising that field hydrogeologists, modellers, and regulators all need to manage data, the purpose of developing the hydrogeological database concept (called HYGES) was to integrate the main data and information that the hydrogeologist uses. The objectives for the final database were: (1) to provide an organised scheme for capturing, storing, editing, and displaying geographically referenced hydrological data and information, (2) to process and analyse spatially distributed data, (3) to properly support aquifer-vulnerability assessments, (4) to easily provide values for numerical-model parameters and variables, and (5) to create hydrogeological maps.

Existing and required data types were examined in order to design the database scheme. Parameters and information were reclassified and regrouped several times. Many hydrogeological parameters and relationships were analysed in order to be placed in the database. Maximum information, minimum data redundancy, reduction of storage capacity, and optimum retrievability of data for analysis were the constraints that defined the final scheme. Data-integration limits were imposed because of different restrictions concerning the hardware and software storage capacity and limitations in current activities and in available information. 
Table 1 Layers of the primary hydrogeological database. DBMS Database Management System; $Q M$ quarries and mines

\begin{tabular}{|c|c|c|c|c|c|}
\hline $\begin{array}{l}\text { Layer } \\
\text { no. }\end{array}$ & Groups of layers & Characteristics represented & Geometry & $\begin{array}{l}\text { Main table } \\
\text { DBMS }\end{array}$ & $\begin{array}{l}\text { Structure and } \\
\text { format }\end{array}$ \\
\hline 1 & Topography & Land elevation - contour lines & Arc & - & Info \\
\hline 3 & Map of soils & Soils & Polygon & - & Info \\
\hline 4 & Surface-water bodies & Surface waters (lakes, ponds) & Polygon & Hydro & Info+Access \\
\hline 7 & Irrigation drains & Irrigation drains (unexploited) & Arc & Drain & Info+Access \\
\hline 8 & $\begin{array}{l}\text { Surface water (point) } \\
\text { Qualitative measurement sections } \\
\text { Springs } \\
\text { Springs for water supply } \\
\text { Swallow holes and resurgences } \\
\text { Irrigation drains }\end{array}$ & $\begin{array}{l}\text { Quantitative measurement sections } \\
\text { Point } \\
\text { Point } \\
\text { Point } \\
\text { Point } \\
\text { Point }\end{array}$ & Point & Surface & Info+Access \\
\hline 11 & Quarries and mines & Quarries, mines - description & Polygon & QM & Info+Access \\
\hline 12 & Water-supply galleries and drains & Water-supply galleries and drains & Arc & Gallery & Info+Access \\
\hline 13 & Protection zones & Protection zones & Polygon & Zones & Info+Access \\
\hline 14 & Hydrogeologic cross sections & Hydrogeologic cross sections & Arc & - & Info \\
\hline 15 & Sewer network system & Sewer network system & Arc & - & Info \\
\hline 16 & Karst atlas & Karst geomorphology & - & - & Info \\
\hline 17 & $\begin{array}{l}\text { Land-use map (three layers) } \\
\text { Communities } \\
\text { Provinces }\end{array}$ & $\begin{array}{l}\text { Topographical map } \\
\text { Polygon } \\
\text { Polygon }\end{array}$ & $\begin{array}{l}- \\
- \\
-\end{array}$ & $\begin{array}{l}- \\
\text { Info } \\
\text { Info }\end{array}$ & Topo raster map \\
\hline
\end{tabular}

\section{Technical Aspects of the HYGES \\ Database Construction}

Data analysis is an important consideration in database construction. In order to identify the data needs and to provide the optimal data representation, accurate assessments of all types of data and data formats are extremely important before designing a database.

The data-collection operation showed that hydrological and hydrogeological data come from very different sources: water regulators, water companies, environmental agencies, geological research organizations, and many others. In this case, the main data providers were the Ministry of Walloon region; Walloon Society for Water Distribution (SWDE); Water Supply Company of Liege (CILE); Water Supply Company of Brussels (CIBE); Belgian Geological Survey; Laboratory of Engineering Geology, Hydrogeology and Geophysical Prospecting (LGIH); and others. These various sources have strong dissimilarities in data type, in quality and in quantity, as well as in storage media. All the data were analysed for transfer to a single system. Data that appear to be redundant had to be specified in the database scheme to avoid loss of information. Such decisions were based on (1) pumping schedules, (2) data-registration formats, (3) uncertainty of existing data (measures and registration), and (4) insufficiency in data-registration system.

Depending on the characteristics of the accepted conceptual model (basic assumptions) and needs, additional data could appear. Also, data that were not explicit or sufficient needed to be flagged or supplied with fields of information or even entire tables. An example is the case where flow-rate registrations related to several wells were available, without distinguishing the pumping schedule of each well. There, a field containing wells sharing the same flow-rate value had to be specified.

Data formats are also an important issue, because the pre-treatment of data consists of hours of encoding or of writing import/export codes. Data coming from paper sources, such as tables, maps, and singular data, as well as different spreadsheets and data existing in databases having distinct schemes, were analysed in order to create a unified database system.

After structuring the spatial-database scheme, hydrological and hydrogeological data, obtained from the Ministry of Walloon region, SWDE, CILE, and elsewhere were introduced into a GIS project using Arc/Info (Envi-

Fig. 4 Simplified version of the attribute data scheme for "surfacewater points" 


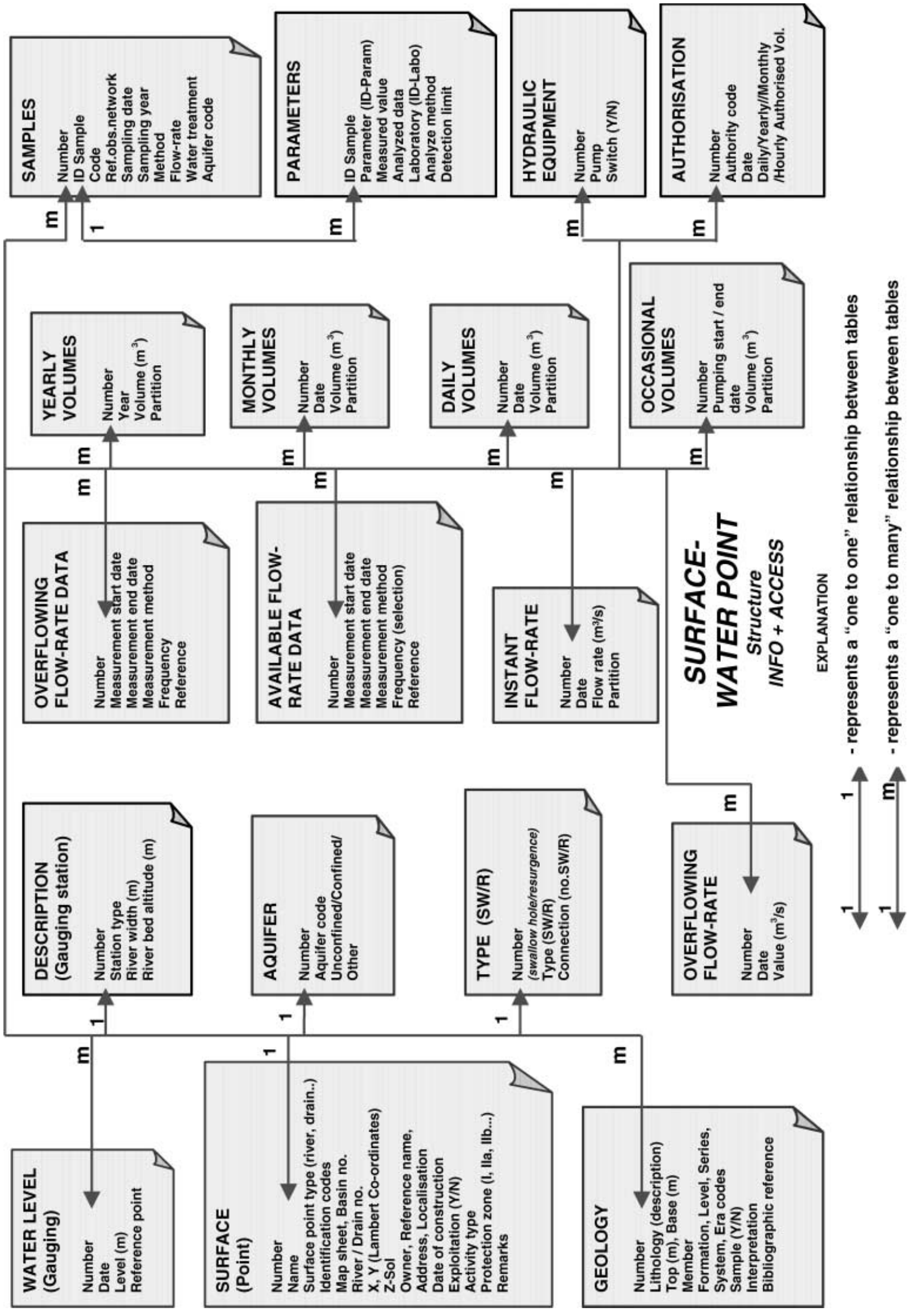


ronmental Systems Research Institute, ESRI) with Access (Microsoft). This solution was chosen after analysing the software platforms used by different hydrological and hydrogeological research teams, Belgian regulators, water companies, and water authorities, in order to ensure compatibility in future data-exchange operations.

In the first step, information was collected for the following hydrogeological entities: wells and wells systems, piezometers, drains, water-supply galleries, and quarries and mines exploited for water. For these features, the following characteristics were incorporated: location (in Belgian Lambert coordinates), address, altitude, depth, local aquifer information, and owners. More than 50 years (1947-1999) of time-dependent data were encoded, including hydraulic heads and annual and monthly pumping rates. Quality data represented by 147 water-quality parameters determined on 2,316 groundwater samples are now registered in the database. The information was supplemented with digital maps showing the geology and strata elevations, land-use maps, zones of hydrogeological protection, and others.

\section{Description of the HYGES Database Scheme}

Data and information specific to geomorphologic, geologic, and hydrologic conditions were divided into two parts, primary and secondary data. The primary-data section contains layers of general environmental information, such as topography, geological maps, soils maps, hydrological and hydrogeological raw data, or data undergoing an initial minor pre-treatment; information related to hydrogeological investigations and developmental means, such as wells, piezometers, drains, mines, and quarries; and land-use maps. Secondary data consist of data derived from processed primary data; examples include maps of hydraulic head, hydraulic conductivity, and groundwater vulnerability.

A spatial reference for the represented hydrogeological features was used based on the topographical map of Belgium at a scale of $1: 25,000$. This map uses the Lambert Conformal Conic projection with the following parameters (Belgium Lambert): spheroid International 1909; 1 st standard parallel $49^{\circ} 50^{\prime} 0.002^{\prime \prime} \mathrm{N}$; 2nd standard parallel $51^{\circ} 10^{\prime} 0.002^{\prime \prime} \mathrm{N}$; central meridian $4^{\circ} 22^{\prime} 2.952^{\prime \prime} \mathrm{E}$; latitude of projection's origin $90^{\circ} 0^{\prime} 0.000^{\prime \prime}$; false easting (meters) 150000.01300; and false northing (meters) 5400088.43800. The current geological map of Belgium uses the same scale and the same projection as the topographical map.

The composition of the primary database is given in Table 1, which shows that the information is divided into several groups of layers. One or several layers compose each information group. The number of layers, the name of each layer, the represented entities, the format or geometric characteristic, and some characteristics of the attribute database link to GIS layers are specified in the same table. Topography is represented by contour lines. Because of the available encoded data, the "geological map" and the "map of soils" are polygon layers and simple attributes are attached directly to them. The same approach is applied to the "karst geomorphology atlas", "land-use plan", and "sewer network system". The "hydrogeologic cross sections" are represented by line features. They have attached computer-aided design (CAD) drawings or scanned images showing the cross sections. Point information is classified into two main layers, depending on the position relative to the ground surface: "surfacewater points" and "groundwater points".

\section{"Surface-water points" information layer}

The information layer "surface-water points" contains points representing river-gauging information, waterquality sampling data, irrigation-drain point data, springs, springs used for water supply, and swallow hole and resurgence hydrogeologic characteristics. The attribute scheme of this layer, shown in Fig. 4, contains several related tables. Surface is the main table where using a relation of "one to one", the scheme is linked to the geographic location of the point in the GIS software. The linkage is done through the unique item called "Number" at the top of each table. The relationships "one to one" and "one to many" between the Surface table and the various derived tables marked " $\mathrm{m}$ " are defined using the same item. The Water levels and Description (Gauging station) tables contain the characteristics of river cross sections. Geology and Aquifer are tables that are needed to describe the environmental conditions of springs, water-supply springs, surface drains (irrigation), and karst features. The Type (Swallow hole/Resurgence) table is specific to the karst features. The table Aquifer shows the connection to the water-supply springs via the tables Overflowing flow rate and Overflowing flow-rate data, as well as to the swallow holes and resurgences. As seen in Fig. 4, six tables of flow-rate data are introduced: Water level (gauging), Description (gauging station), Overflowing flow rate, Overflowing flow-rate data, Available flow-rate data, and Instant flow rate. Specific data for the water-supply springs are also stored in Hydraulic equipment and Authorisation tables. Waterquality data for all the six entities represented in this layer are described using the Samples and Parameters tables.

\section{"Groundwater points" information layer}

The "groundwater points" information layer is registered in the database with a more extended attribute scheme. This layer regroups the following entities: wells, traditional hand-dug wells and simple piezometers, galleries and gallery wells, rock quarries and mines; and boreholes. The main table linked to the layer points is Groundwater. The relationships between tables are made using the unique layer item at the top of each table, also called "number". As shown in Fig. 5, the table Groundwater contains information concerning the geographic

Fig. 5 Simplified version of the attribute data scheme for "groundwater points" 


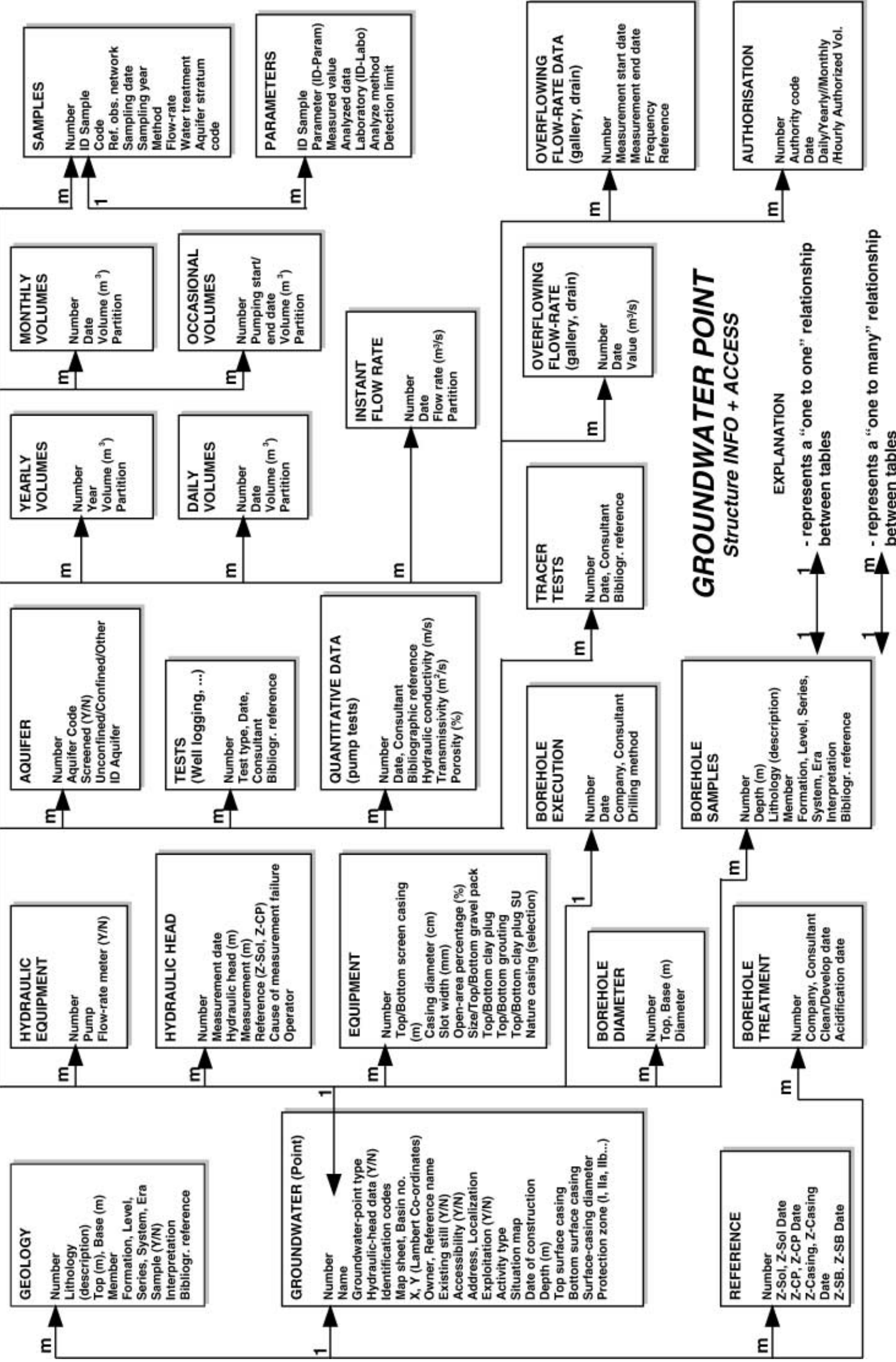


Fig. 6 A spatial database query menu for hydraulic heads

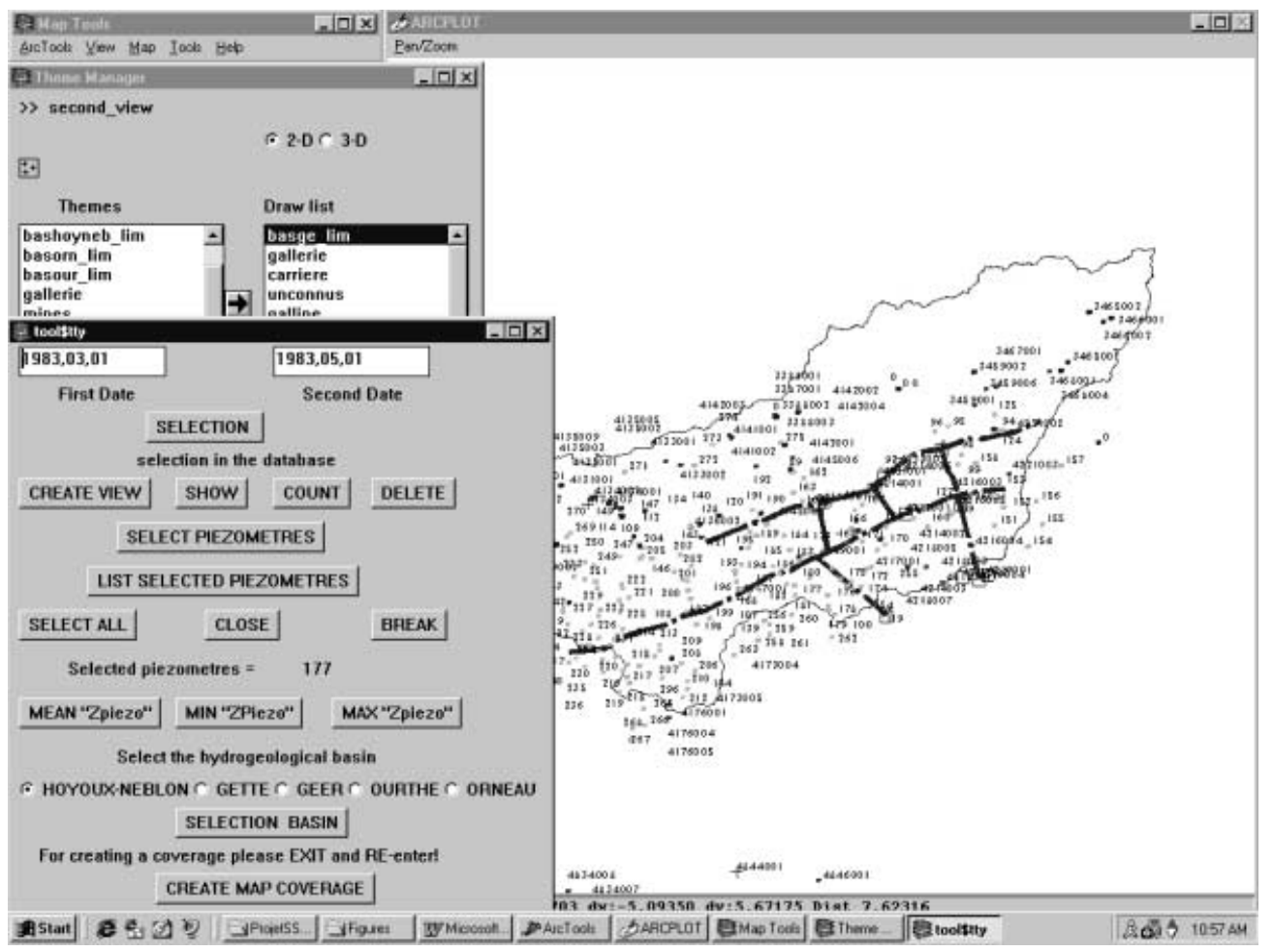

position (coordinates, address), type of represented entity (well, traditional well, borehole, gallery well, piezometer, etc.), name (or official names), system of codes (used by several regulators in order to identify the entity), and some technical characteristics related to the represented entity (such as date of execution, type of exploitation, depth, kind of a protection zone to which it belongs, and others).

Data containing the lithology and stratigraphy are in the Geology table. Each stratum penetrated by a borehole is described here by a "one to many" relationship. Other information related to the borehole and geological parameters (considering that each well or piezometer is initially a borehole) is included in the tables: Borehole diameter, Borehole execution, Borehole treatment, Borehole samples, and Reference. Information related to the tests conducted in the boreholes (well logging, etc.) is stored in the table Tests. Data related to technical characteristics of wells and equipment are in the tables under Hydraulic equipment and Equipment. The table Equipment is used to store information relating to the completion of wells.

The Aquifer table is used to store information that describes the succession of aquifer strata penetrated by wells. The code of the aquifer (placed in a dictionary of terms), whether the aquifer is under confined/unconfined conditions, as well as the position of the screens, are stored here. The hydraulic-head values are stored in the Hydraulic head table. Seven tables representing diverse kinds of flow-rate measurements are present. Two of them contain specific data for galleries and drains (Fig. 5).
Information that identifies the analysed groundwater quality samples and describes the results is stored in two tables (Samples and Parameters). Because for each analysed sample several parameters are identified, a "one to many" relationship is established. The link is made using a unique point item called Sample-ID. The Samples table contains the sample code, the sampling date, the sampling method, the value of the flow rate when the sample was taken, the water treatment technique, and the aquifer stratum code where the sample has been taken. The Parameters table contains the name of each measured parameter (in a dictionary of terms), its respective value, the date the analysis was done, the analysis type, and its limit of detection. Also, the name of the laboratory and its coordinates are introduced here in a dictionary of terms.

Information about hydrogeological tests is stored in the table Quantitative data (information related to quantitative tests made in a well) and in the Tracer tests table (an inventory and references of the performed tracer tests). Representative values of hydraulic conductivity (in meters per second), transmissivity (in square meters per second), and porosity (in percent) parameters associated with a bibliographic reference are also stored here. A table containing the authorised volumes of extracted water for each well (approved by regulators) completes the scheme. The Authorisation table represents a good reference for the environmental-impact studies and other hydrogeologic investigations.

"Climatic stations" are represented in the analysis as a separate layer of points having also an attached attribute scheme. Simpler attribute schemes are developed also 


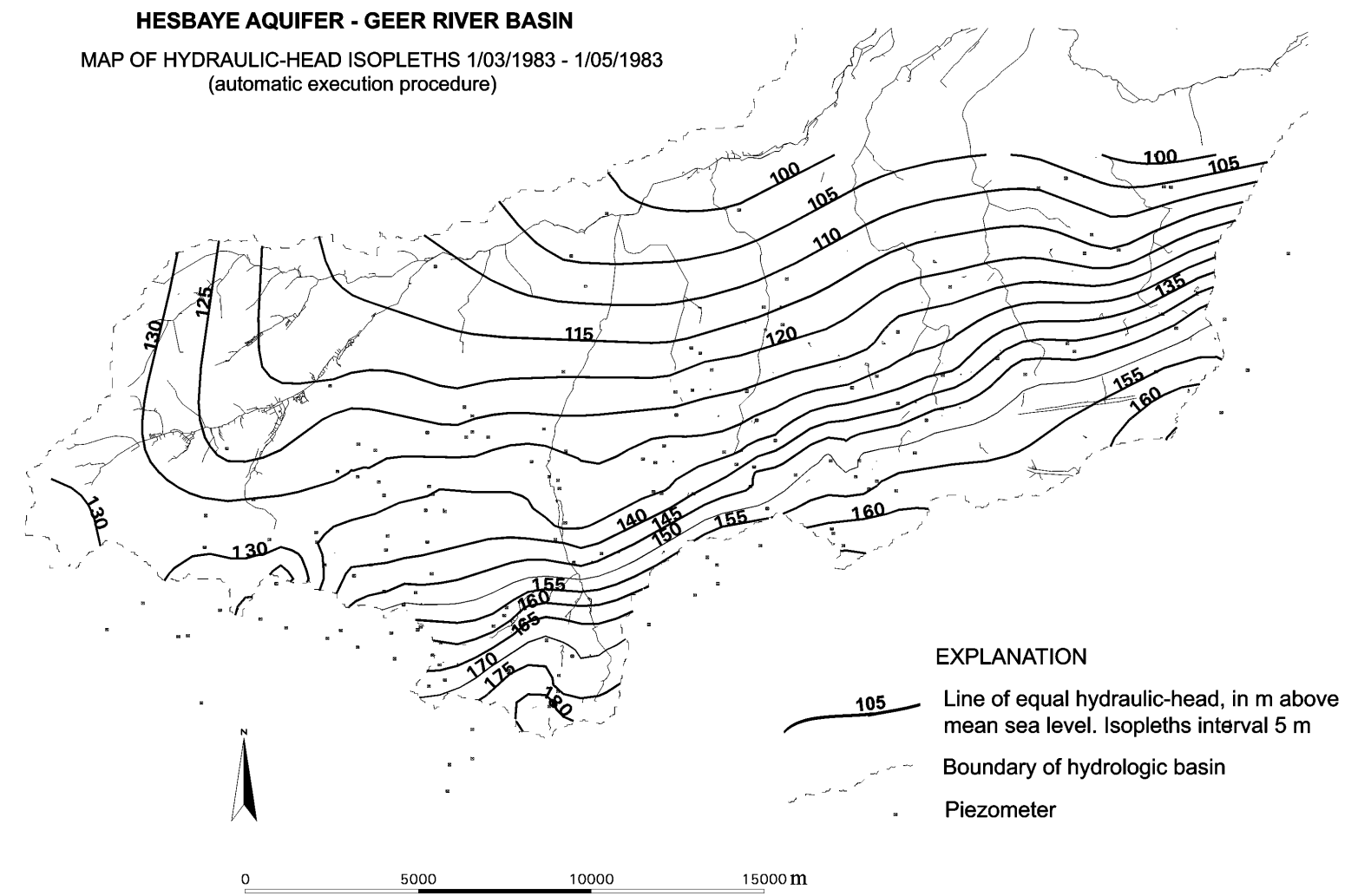

Fig. 7 Map based on the generating procedure for obtaining isopleth maps of hydraulic heads

for "Hydrological network" (line), "Tables of surface water" (polygon), "Irrigation drains" (line), "Quarries and mines" (polygon), "Water-supply galleries and drains" (line), and "Protection zones" (polygon).

\section{Spatial Analysis of Hydrogeological Data Using GIS}

Powerful spatial analysis is feasible once the database is established. Maps representing database attribute queries (time- and space-dependent parameter values) can be created. Simple statistics related to hydrogeological entities can be displayed on the computer screen or printed on paper support maps. Geostatistical procedures (i.e., kriging) complete the analysis. Some of the tools needed to achieve the objectives are already implemented in the base software package, but most of them require knowledge of GIS techniques, database philosophy, and targeted programming using specific programming languages.

In this case, spatial query procedures having a userfriendly interface were written in AML (Arc Macro Language) and SQL (Standard Query Language). These new query tools were designed to complete and combine the existing GIS package functions. Now, maps displaying maximum, minimum, or mean values of hydraulic heads for a required period of time can be automatically displayed by choosing the required dates; an example is shown in Fig. 6. Also, the number of hydraulic-head measurement points and the associated standard devia- tion can be shown. Flow rates of wells or a specified pumping schedule can be displayed in the same way graphically or on maps. In addition, new layers or new maps resulting from the inclusion of any existing layer of information can be generated.

Using a chosen interpolation procedure, results obtained by different queries can be treated further. Obtaining maps of hydraulic-head distribution for a chosen time interval is one possibility. Spatial interpolation can be done by using the existing software tools or by programming new ones. Arc/Info contains several reliable tools for interpolation. The information contained in the vector format layer has to be rasterised to apply these tools. To do this, the information layer has to be transformed into a uniform cell-based grid, where each cell is assigned the attribute information. In order to increase the accuracy of interpolated results, the cell size should be chosen based on the spatial distribution and accuracy of the data. In this case, to obtain isopleths of hydraulic heads, the cell size was selected taking into account the spatial distribution of the point information in the hydrological basin, the basin area, the distance between point hydrogeological entities (wells, piezometers, etc.), and the computing time. The interpolation method uses an iterative finite-difference interpolation technique. It is optimised to have the computational efficiency of "local" interpolation methods such as inverse distance weighted interpolation (Environmental Systems Research Institute 1997). Isopleth maps of hydraulic heads can be generated using the optimised grid of interpolated hydraulic heads; an example is shown in Fig. 7. 


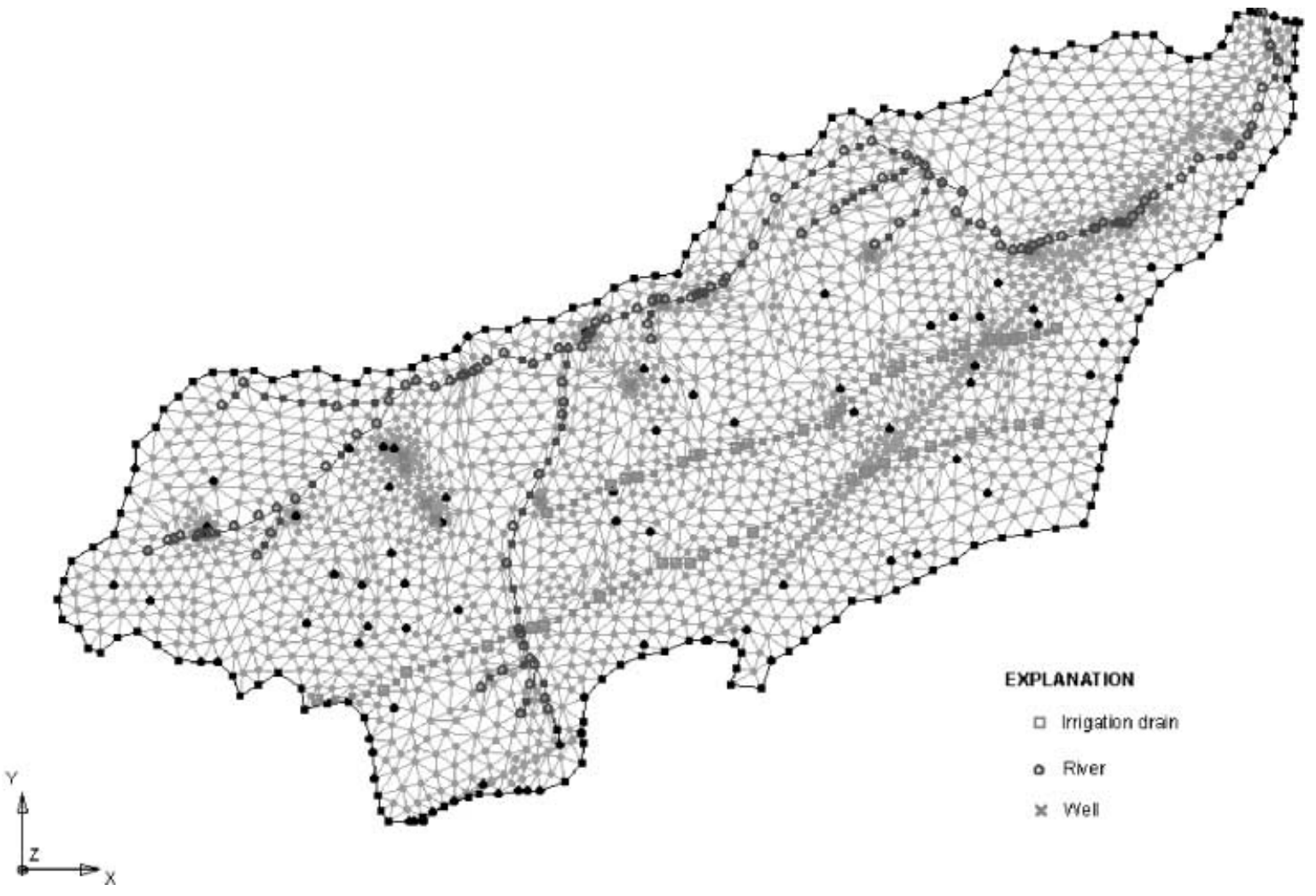

Fig. 8 A 2D finite-element mesh generated using "feature objects"

\section{Particular Aspects of Groundwater Numerical Modelling}

The Groundwater Modelling System (GMS) is a powerful pre-processor and post-processor (Engineering Computer Graphics Laboratory 1998) that can be used for various groundwater numerical modelling operations. For simulating the groundwater flow in the concerned hydrogeological basins, numerical models were created using this package with the SUFT3D (Carabin and Dassargues 1999) finite-element software and the MODFLOW (McDonald and Harbaugh 1988) finite-difference software.

For the chosen GMS version (GMS 2.1, 1998), the hydrogeological-attribute data can be directly introduced or they can be imported from a specific format file. The need for importing data in GMS exists in the three steps of groundwater flow modelling: conceptual model design, model construction, and calibration.

The boundaries, constraints, stresses, and other features defining the conceptual model are created using the socalled feature objects represented by points, arcs, and polygons. Points define pumping wells and piezometers; arcs define boundaries, rivers, and drains; and polygons define different material zones as well as water surfaces (lakes). For 3D modelling, triangular irregular networks (TINs) are used to represent the ground surface and the theoretical surfaces between the limits of geological strata. These "feature objects" can be imported in GMS from GIS packages.
Starting from the defined conceptual model, the model can be built within GMS using automatic tools. Depending on the chosen model (finite element or finite difference), the method of using these tools is different. For finitedifference models, serried attributes can be given to all "feature objects". These include pumping rates and stress layers for wells, prescribed total heads for boundaries and lakes, elevations and conductances (hydraulic conductivity of the prevailing thickness of the streambed) for rivers and irrigation drains, hydrogeological properties of each stratum, and recharge rates for the defined areas. The finite-difference grid is automatically constructed to fit the conceptual model and the data are transposed from the conceptual model to the grid cells. For the mesh of the finite-element models, only the material properties can be imported. GMS uses the "feature objects" defining the conceptual model to generate a $2 \mathrm{D}$ mesh, such as is shown in Fig. 8. The procedure follows the geometric constraints; refinements may be required around points and element sides corresponding to arc edges. The 3D mesh is built using the 2D mesh and TINs.

Model calibration is the process of modifying the input parameter values until the model output matches an observed data set. In groundwater modelling, the observed data are usually the point values of the hydraulic head, and a set of "observation points" can be imported in GMS, allowing further statistical treatment.

\section{Coupling HYGES to the GMS Interface}

GMS contains several tools for exchanging data with GIS packages, but a real coupling tool has not been 
Fig. 9 Interface menu for creating readable Groundwater Modelling System (GMS) files and new layers of processed information

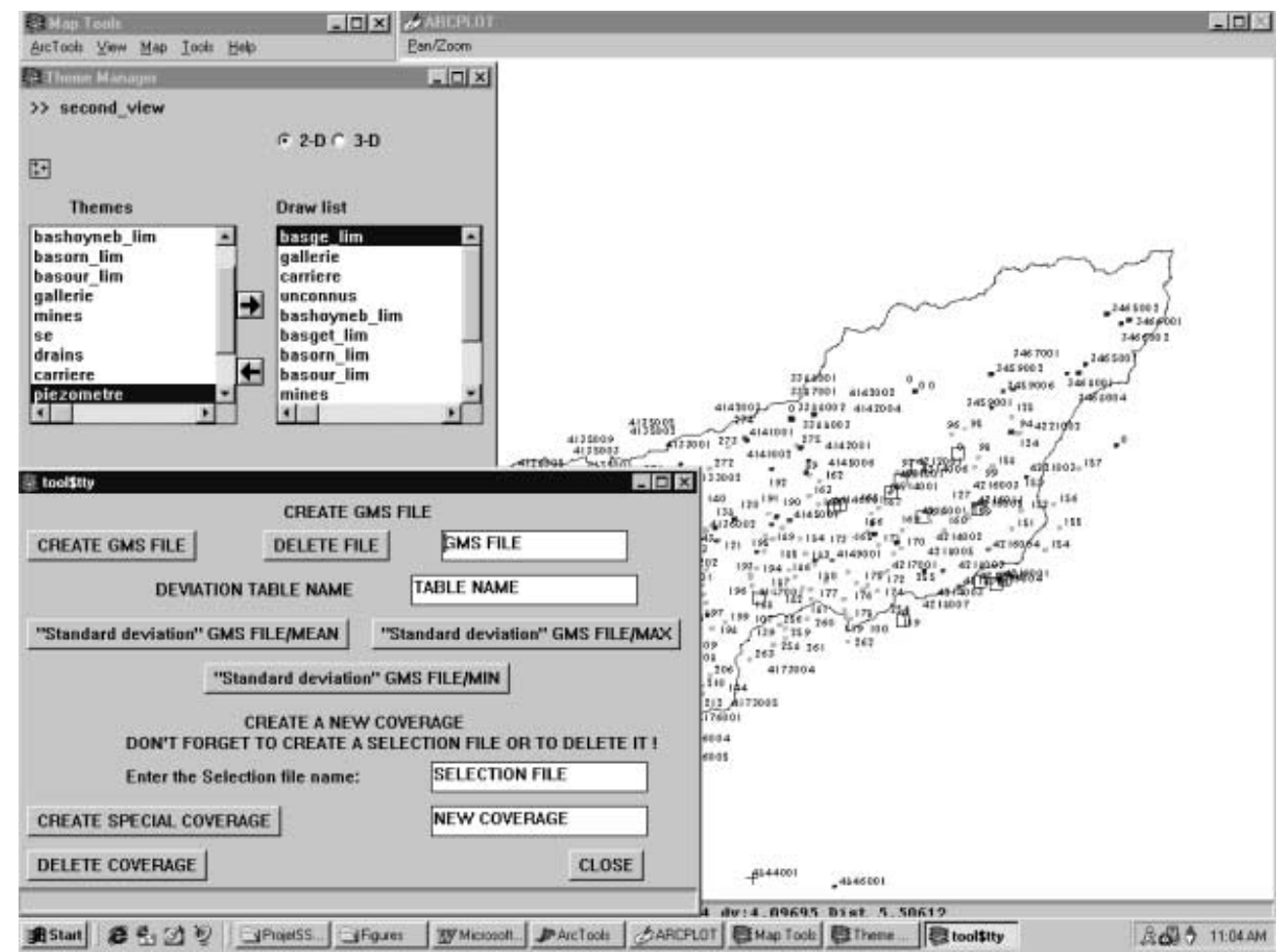

developed yet. Arc/Info can interchange geometric data (point, arc, and polygon) with GMS through the existing "Generate/Ungenerate" functions. Attribute data cannot be automatically exchanged; however, GMS is continuously being improved to meet users' requirements. Enlarging the GMS software capacities through programming could theoretically solve this issue, but in practice this depends on the entire spatial data scheme (geometric features layers and attribute data) or even on the database structure.

In order to solve the coupling aspect, different programs were developed to automatically use the attributes of wells, rivers, and drains in GMS for the mesh of the finite-element models. They make the attribute-data transfer between Arc/Info and GMS software through "feature objects" and "observation points". The codes were created using Arc Macro Language (AML) and Standard Query Language (SQL). These programs represent a coupling tool between the GIS package and the groundwater modelling software. This tool allows maintenance of the coupled software packages as independent systems, facilitating any future changes in the spatial database scheme or in any particular module of the software.

A user-friendly interface, illustrated in Fig. 9, manages the data query and transfer for the "loose coupling" tool. By introducing several query characteristics (spatial or time dependent) for flow rates or hydraulic-head values, a readable GMS file is easily created. Further, GMS handles this file for attributing values (flow rates, hydraulic-head values, and statistical parameters) to each location point of the model discretisation.

\section{The Hydrogeological Database Scheme Within a GIS Structure}

The presented scheme can satisfy the hydrogeologist's immediate needs in terms of research and various environmental studies. However, hydrogeologists are advised that a complete GIS structure is more that a database scheme. The scheme implementation within a complex GIS structure supposes another design step related to concepts and formalisms (Pantazis and Donnay 1996). First of all, "GIS development is a process of technological innovation and requires management attention appropriate to this type of activity very dependent on proper management participation and supervision" (New York State Archives and Records Administration 1997).

Even though this complex direction is beyond the objectives of the present work, the main tasks that must be completed to have a successful organisational GIS are discussed. As stated by the above-mentioned institution, these are: Needs Assessment, Conceptual Design of the GIS, Survey of Available Data, Survey of GIS Hardware and Software, Detailed Database Planning and Design, Database Construction, Pilot Study and Benchmark Test, Acquisition of GIS Hardware and Software, GIS System Integration, GIS Application Development, and GIS Use and Maintenance. These steps are related, as illustrated in Fig. 10.

\section{Conclusions and Further Developments}

The hydrogeological GIS database described in this paper offers capabilities for hydrogeological modelling 
Fig. 10 Relationships between the main steps of a GISdevelopment process

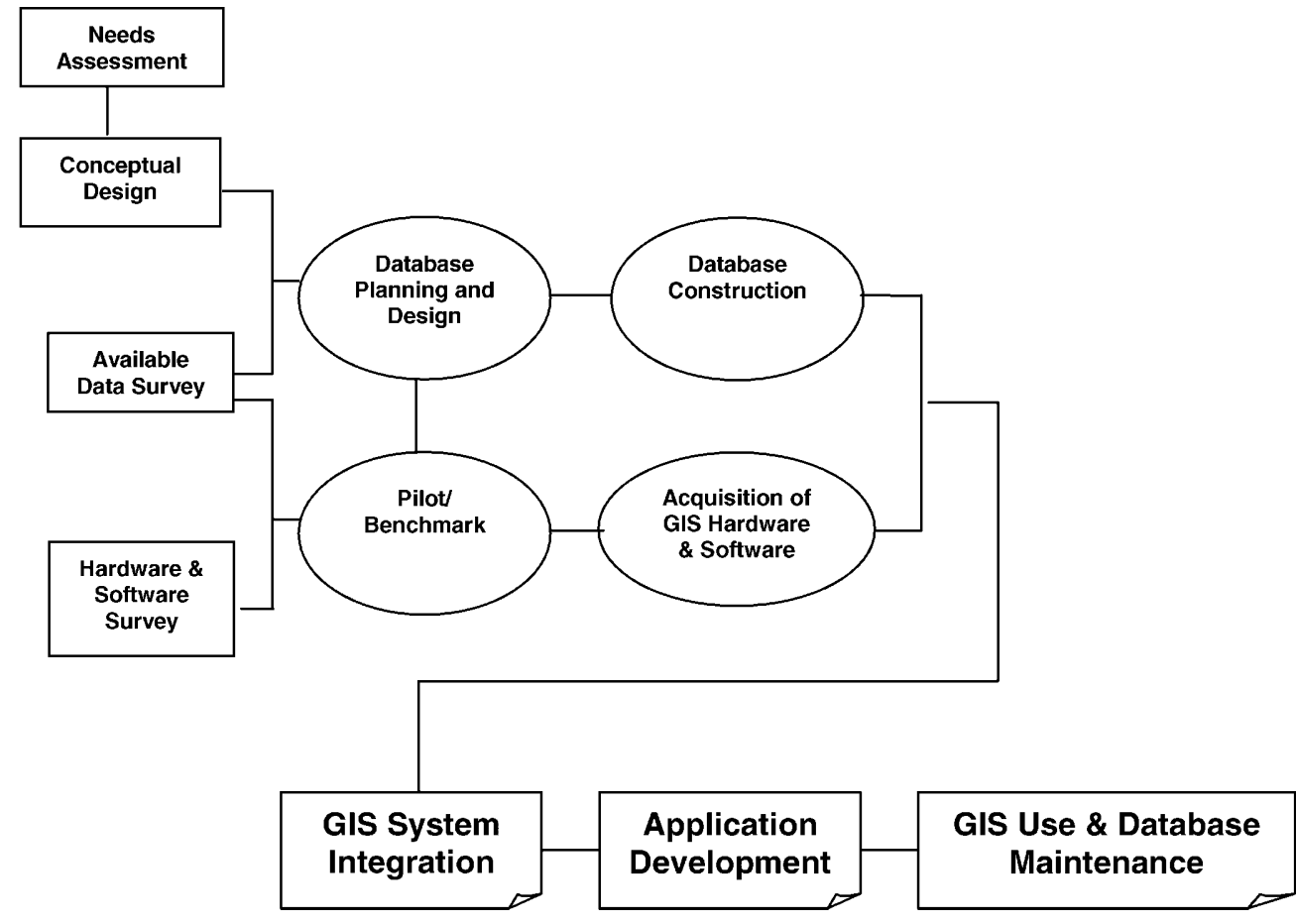

as well as other hydrogeological studies, as described below:

1. Data verification and validation are essential. Using an advanced database supported by GIS, this operation could be done in a simple way. For example, anomalies in hydraulic-head data could be observed directly on the generated hydraulic-head maps.

2. Automatic data treatment is required before input to the numerical model. Because of the huge amount of work that is required to prepare the data used in the process-based models, the GIS database is essential.

3. A global view of the hydrogeological data can be obtained by using the generated maps. Hydraulichead maps, maps of pumping-rate allocations, and maps of statistical data show very clearly the data distribution and allow a view of conditions of the aquifer behaviour and stress factors.

4. Maps of aquifer parameters can be generated. They can be created starting from existing point data using statistical procedures (geostatistics) supported by the GIS software. These maps are needed to start the calibration procedure of any groundwater model. Potential sites for groundwater utilisation can be detected using these maps. The vertical variability of hydrogeologic parameters (e.g., hydraulic conductivity, porosity) that have a great influence on the conditions for extracting water from the aquifer also can be analysed.

5. Correlations between groundwater hydrochemical parameters, aquifer depth, lithology, and land use can be made using the recorded data and statistical procedures already implemented in the GIS software.

6. Aquifer vulnerability studies can be performed using the existing spatial database. New procedures for quantification of physically significant parameters can be developed using this hydrogeologic database. From this point of view, coupling GIS to processbased numerical models with applications to groundwater phenomena as well as to the unsaturated zone would represent one of the most interesting steps in future hydrogeological research.

The presented database schema is implemented in the Laboratory of Engineering Geology, Hydrogeology and Geophysical Prospecting of the University of Liege, Belgium. The software support is Arc/Info (Environmental Systems Research Institute 1997) in connection with Access (Microsoft). The schema could be applied to other GIS and Relational Database Management Systems (RDBMS) that may be connected.

This database still has limitations which were discussed in the previous sections. However, the authors consider that this scheme fully satisfies the requirements of their hydrogeologic studies. Changes, updates, or further developments of the schema could be incorporated in a simple way. At the same time, the database was designed so that its flexibility makes the dataretrieval process easy. Also, the spatial database was conceived as being modular. Users who are using only an RDBMS in the absence of a GIS tool can handle the attribute data.

Starting from this schema, new developments are already underway. One of them consists of designing new hydrogeological maps for other areas. A pilot project was set up and regulators and researchers are working together to implement this database concept in Belgium for the Walloon region administration. 
Acknowledgements This work was supported by the Belgian Office for Scientific, Technical and Cultural Affairs (SSTC) in the scope of the project (CG/DD/08) "Integrated Modelling of the Hydrological Cycle in Relation to Global Climate Change". The first author warmly thanks the Belgian Office for Scientific, Technical and Cultural Affairs (S \& T Cooperation Belgium - Central and Eastern Europe), which supported the research effort. Particular thanks are given to James Petch, University of Manchester, Andrew Piggott, National Water Research Institute of Canada, and to an anonymous reviewer for their helpful technical reviews.

\section{References}

Belgian Office for Scientific, Technical and Cultural Affairs, Modèle Hydrologique Intégré pour la stumzlation du cycle de l'Eau (2001) [Integrated modelling of the hydrological cycle in relation to global climate change.] Scientific Rep 2000, Global Change-Sustainable Development Programme, Brussels

Carabin G, Dassargues A (1999) Modelling groundwater with ocean and river interaction. Water Resour Res 8:2347-2358

Carabin G, Dassargues A (2000) Coupling of parallel river and groundwater models to simulate dynamic groundwater boundary conditions. In: Bentley LR, Sykes JF, Brebbia CA, Gray WG, Pinder GF (eds) Computational methods in water resources, vol 2. American Geophysical Union, Washington, DC, pp 1107-1113

Corwin DL (1996) GIS applications of deterministic solute transport models for regional-scale assessment of non-point source pollutants in the vadose zone. In: Corwin DL, Loague $\mathrm{K}$ (eds) Applications of GIS to the modelling of non-point source of pollutants in the vadose zone. Soil Sci Soc Am 48:69-100

Dassargues A, Marechal JC, Carabin G, Sels O (1999) On the necessity to use three-dimensional groundwater models for describing impact of drought conditions on streamflow regimes. In: Proc IUGG 99 Symp HS1 Hydrological extremes: understanding, predicting, mitigating, Birmingham, UK, July, IAHS Publ 255, pp 165-170
Engineering Computer Graphics Laboratory (1998) Groundwater modelling system reference manual (GMS v2.1). Brigham Young University, Provo, Utah, USA

Environmental Systems Research Institute (1997) The Arc/Info version 7.1 software package documentation. ESRI, Redlands, California

Goodchild MF (1996) The application of advanced information technology in assessing environmental impacts. In: Corwin DL, Loague K (eds) Applications of GIS to the modelling of non-point source of pollutants in the vadose zone. Soil Sci Soc Am 48:1-17

Heuvelink GBM (1998) Error propagation in environmental modelling with GIS. Taylor and Francis, London, UK

Intergraph (1995) Working with environmental resource management applications (ERMA) groundwater modeller for the Windows NT operating system. Intergraph Corporation, Huntsville, Alabama, USA

Levene M, Loizou G (1999) A guided tour of relational databases and beyond. Springer, Berlin Heidelberg New York

McDonald MG, Harbaugh AW (1988) A modular three dimensional finite-difference groundwater flow model. Techniques of Water-Resources Investigations TWI 06-A1. US Geological Survey, Reston, Virginia, USA

New York State Archives and Records Administration (1997) Geographic information system development guides. State Archives and Records Administration 9B38, Cultural Education Center, Albany, New York, USA

Pantazis D, Donnay JP (1996) La conception de SIG. Méthode et formalisme [The GIS conception. Method and formalism]. Hermes, Paris, France

Sohier C, Moeremans B, Deglin D, Dautrebande S (2001) Validation of the new catchment hydrological model EPIC-GRID for soil moisture evaluation and discharges simulation. In: Proc Conf on The Future of Distributed Hydrological Modelling, Hydrological Processes, Leuven, Belgium, 12-15 Apr, Spec Issue (in press)

Steyaert LT, Goodchild MF (1994) Integrating geographic information systems and environmental simulation models: a status review. In: Michener WK, Brunt JW, Stafford SG (eds) Environmental information management and analysis: ecosystem to global scales. Taylor and Francis, London, UK, pp 333-355 